\title{
Using Padlet in instructional design to promote cognitive engagement: a case study of undergraduate marketing students
}

\author{
Lucy Gill-Simmen \\ Royal Holloway, University of London
}

\begin{abstract}
This case study illustrates the incorporation of Padlet to support a learning task designed to promote student engagement. Padlet was introduced as a digital technology platform in an undergraduate marketing class for an assessment where the stakes are considered low, that is, a formative assessment. The previous cohort had declared it difficult to engage with the original assessment, which took the form of a 1000-word written piece. To facilitate interest and motivation in the task, Padlet was introduced with the assumption that students would engage more with a task if a technology-based instructional design was implemented. This case study examines the use of Padlet to provide a platform for literacy beyond the written text, aimed to increase effort and cognitive engagement. Selfreported results indicate that students find a task supported by the use of Padlet deeply cognitively engaging. Padlet, as illustrated in this case study, could be used in either an inperson or online learning environment.
\end{abstract}

Keywords: Padlet; online learning tools; cognitive engagement; teaching and learning.

\section{Introduction}

Engagement is characterised by three dimensions: cognitive, emotional and behavioural. The concept of cognitive engagement draws on the idea of investment and includes students' willingness to invest and exert effort in learning (Fredricks et al., 2004). For decades, technology has been known to operate as a hook which motivates students to participate through sustained interest and cognitive engagement (Kuh and $\mathrm{Hu}, 2001$; Mo, 
2011; Schindler et al., 2017). Laird and Kuh (2005) identified a strong positive relationship between using information technology for educational purposes and involvement in effective educational practices such as active and collaborative learning. With the use of technology, students' feelings of autonomy and cognitive engagement are elevated through being given an alternative method to explore a topic and to represent their understanding (Blumenfeld et al., 2006). Furthermore, visual representation generated through various modes of ICT helps learners to internalize knowledge and to learn better than through more traditional methods of representation such as written work (DeWitt et al., 2015).

To promote engagement with an individual formative assessment task - a low-stakes learning scenario - a digital assessment was introduced. Padlet was chosen as a tool to support the task given that it affords knowledge development and construction, content aggregation and organization and offers a multi-user interface. Such Padlet capabilities enable flexible learning, support autonomy, and have the potential to support the active engagement of students in the learning process (Park, 2013). In light of the recent shift in many HE institutions to a blended learning approach, the use of platforms as collaborative and engaging learning tools in instructional design is gaining traction (Shinde, 2020). This case study examines the use of Padlet as a platform for a formative assessment analysing a chosen industry.

\section{Background}

With most students bringing a smartphone or other mobile device to class, Web 2.0 technologies present opportunities to improve learner engagement (Ellis, 2015). As computer-based technology has permeated the education sector, its use in effectively promoting student engagement has attracted much attention in higher education due to its association with a number of positive academic outcomes (Schindler et al., 2017). Particularly in light of the recent shift to a blended learning approach, universities that fail to effectively integrate technology into the learning experience may miss opportunities to improve student outcomes. One of the key findings in the literature on technology implementation is the power that technology has in engaging students in relevant learning, 
particularly evidenced by the use of technology in increasing student motivation and participation (Schindler et al., 2017). Light et al. (2009, cited in Bree, 2017) suggest that technology is important as a means of encouraging or supporting learning, provided it has added value for the learner. Digital applications have been shown to have the power to engage and motivate learners, and in fact have the potential to increase academic achievement from the perspective of both the students and the educators (Courville, 2011; Dervan, 2014). Many technology enthusiasts argue that Gen-Z learners are 'digital natives' with sophisticated technology knowledge and skills which can potentially be harnessed for better learning engagement inside the classroom. However, how to gather information and navigate an abundance of sources still needs to be learned since academic digital literacy skills are distinct from those required in daily life to use technology socially (Gurung and Rutledge, 2014).

Cognitive engagement includes the amount of effort students are willing to put into a task and also how long they are willing to work on it (Corno and Mandinach, 1983; Richardson and Newby 2006). According to Scott and Walczak (2009), the richness of multimedia technology goes so far as to stimulate the senses, thereby encouraging cognitive engagement. Understanding of cognitive engagement can be furthered by distinguishing amongst behaviours on a continuum between deep and shallow engagement (Greene and Miller, 1996). Students who exhibit behaviours that allow them to master academic work are seen to have deep cognitive engagement, whilst students who exhibit behaviours such as purely rote memorization and rituals that they perceive will help them to do well without developing mastery of the material are demonstrating shallow engagement. In the context of this case study, the use of technology to support a task promoting deep cognitive engagement was proposed and measured using student self-reporting.

\section{Case Study}

On a second-year undergraduate in-person Marketing Strategy course at a UK public research university, a difference across the cohort of 400 students was noted in terms of academic ability, learning approach, motivation for and confidence in learning, willingness to participate, spoken and written fluency, and work ethic. The cohort comprised students 
aged 20-22 years with a variety of nationalities - UK 55\%, EU 25\%, and International $20 \%$. In addition, it was noted, both through personal observation and through student evaluation, how difficult it had been for students in previous cohorts to engage with written tasks for an individual formative assessment. The original individual formative assessment method on the module was a written 1000-word industry analysis. Given the nature of the analysis, requiring the use of a number of analytical frameworks, a previous cohort said they found it difficult to write about the industry and that it would be easier to show their findings in tables and diagrams and in a more visual way. Students described the assessment as 'boring' and 'hard to know how to write using the appropriate business level writing style'.

An engaging assessment should meet the needs of a culturally and educationally diverse student population without compromising academic standards, instead improving opportunities for all students to demonstrate their acquisition of the learning outcomes. More specifically, the aims of an engaging assessment are to fairly evaluate students' ability to meet learning outcomes, to be accessible to all students, to provide every student with an equal opportunity to demonstrate their achievement, to support student engagement and learning, and to address the needs of a diverse student population (Hockings, 2010). To meet the requirements of an engaging assessment, the original formative assessment was replaced with a more active and blended learning experience designed to motivate students to exert more effort in a low-stakes situation. To promote engagement, Padlet was identified as the most appropriate digital technology since the wide variety of media supported by Padlet provides a particularly rich environment for engaging in today's complex information environment (Table 1).

Table 1. Padlet features.

\begin{tabular}{|l|l|}
\hline Padlet Features & Impact on Learning \\
\hline $\begin{array}{l}\text { Collaboration through a multi-user interface. } \\
\text { Flexible and versatile for collaborative content } \\
\text { sharing, collective knowledge development and } \\
\text { construction. }\end{array}$ & $\bullet \begin{array}{l}\text { Provides tutor, self and peer assessment } \\
\text { capabilities. }\end{array}$ \\
$\begin{array}{l}\text { Provision for blogging, discussion and social } \\
\text { Bookmarking for Twitter, Facebook, Slack }\end{array}$ & - Allows for synchronous or asynchronous \\
& $\begin{array}{l}\text { Stlaboration. } \\
\text { learning. }\end{array}$ \\
& - Accommodates opportunity for autonomy, \\
& competence and relatedness \\
\hline
\end{tabular}




\begin{tabular}{|c|c|}
\hline & $\begin{array}{l}\text { - Promotes learner engagement. } \\
\text { - } \quad \text { Collaborative as well as independent use. }\end{array}$ \\
\hline $\begin{array}{l}\text { Wide aesthetic appeal. } \\
\text { Choices of wallpaper, typography and themes to } \\
\text { fit a variety of writing styles from sticky notes to } \\
\text { essays. } \\
\text { Different layouts convey information as a square } \\
\text { board, a feed of information, or as an open } \\
\text { canvas. }\end{array}$ & $\begin{array}{l}\text { Promotes visual learning and sense stimulation } \\
\text { through the visual pin-board feature. } \\
\text { Encourages increased time spent on task through } \\
\text { opportunities to showcase content in a variety of } \\
\text { ways. } \\
\text { - Improves information assimilation capacity and } \\
\text { promotes intrinsic curiosity. }\end{array}$ \\
\hline $\begin{array}{l}\text { Wide variety of media and file types supported. } \\
\text { Multiple formatting options, allowing learners to } \\
\text { upload files, post images, documents, videos, } \\
\text { music and embed any web-based content. }\end{array}$ & $\begin{array}{l}\text { - Engages full spectrum of digital literacies. } \\
\text { - } \text { Provides opportunities for learners to readily build } \\
\text { and represent knowledge through multi-media } \\
\text { capabilities. } \\
\text { - Attached links and files appear with a stimulating } \\
\text { contextual preview thus focusing learners' } \\
\text { attention. } \\
\text { - Opportunity to scatter, group, and connect content } \\
\text { allows for visual representation of information, } \\
\text { synthesis and analysis in a variety of ways. }\end{array}$ \\
\hline $\begin{array}{l}\text { Apps for most devices. } \\
\text { Provides accessibility anywhere, anytime with } \\
\text { instant updates and responses in real time }\end{array}$ & $\begin{array}{l}\text { - Multiple points of access promote user interest and } \\
\text { - } \text { Increates higher levels of self-pacing } \\
\text { - } \quad \text { Encourages instant participation }\end{array}$ \\
\hline
\end{tabular}

\section{Task}

At the start of the module, students were fully briefed on the objective of the assessment, which was to research and develop an industry analysis and to present key findings about the industry as a series of ideas on a Padlet wall. Students were required to choose a brand of interest and to conduct an analysis of the marketing environment for the industry sector in which the brand operates. This served as a formative exercise for a subsequent summative marketing plan for their chosen brand. Specifically, students were required to conduct a macro and micro analysis of the chosen industry and to present a synthesis of the current situation of the industry using specific taught analytical frameworks. As such, the remit for the assessment mirrored that of the former written assessment and assessment outcomes remained largely unchanged with the exception of additional assessment outcomes: technology utilisation and use of graphics and pictures. 
Students were provided with a marking rubric in advance. The rubric highlighted the five assessment criteria: 1. Organization and presentation of analyses, 2. Content and accuracy of analysis, 3. Technology utilisation, 4. Use of graphics and pictures, 5. Writing and Grammar. To introduce the use of Padlet as the chosen platform for their assignment, the class was shown the video How to use Padlet, and students were instructed to go to Padlet.com and then click on 'make a Padlet', after which their wall was ready for use. Students were encouraged to make some modifications to their wall, such as giving it a title, changing the background image, giving the wall a unique web address, and changing the display of posts. They were shown how to add to their wall by typing, pasting links, adding pictures, image and audio or video clips.

Students were required to develop their Padlet over a period of five weeks, and the workshop instructors (four in total) had access to the Padlets in order to monitor and offer support in response to student progress or lack of progress. Students were asked to share the link to their Padlet wall with a fellow student in the group, who was required to make comments and to provide peer feedback halfway through the five-week period. Each week, students were required to work on their Padlet based on material taught in weekly lectures and workshops. The aim of the assignment was for students to delve deeper into a class-related topic, thoroughly research it (by reading articles and reviewing videos and websites), selectively summarize and assemble the most useful resources into a creative, engaging, and logically organized Padlet. After five weeks, students exported their links to their final Padlet to an inbox in Moodle (virtual learning environment) for assessment purposes. The Padlets were graded, and formative feedback provided in line with the rubric. Limitations sometimes associated with Padlet, such as limited editing features, preference for short tasks, difficulties with scrolling and difficulty organizing vast amounts of ideas, were not deemed to be challenges specific to this task (DeWitt and Koh, 2020).

\section{Methodology}

Immediately following submission of the Padlet assessment, students were asked to fill in a short questionnaire on Google Forms to self-report the extent to which they estimated their own levels of cognitive engagement (Greene, 2015). The cognitive engagement scale 
developed by Greene and Miller (1996) was adopted, and five items were adapted from the scale and reworded to specifically refer to the set Padlet task. Sub-scales of deep cognitive engagement with the task were measured, specifically self-regulation, deep strategy use and persistence. The questions were developed according to the sub-scales and measured using the following items: planning and organisation of ideas, developing information in new ways, introduction of new ideas, extra reading to enhance understanding of concepts, and continuous checking of ideas. The questionnaire comprised five questions on a Likert scale from 1 to 5 , where 1 equates to strongly agree and 5 to strongly disagree. 320 students filled out the anonymous questionnaire and provided informed consent to share the results. The questionnaire link was made available through the virtual learning environment, Moodle. It was made clear that completion of the survey was not compulsory. Responses were transferred from Google Forms to Microsoft Excel 2013 for analysis.

\section{Findings}

The survey findings are shown in Table 2. It is apparent that on all cognitive engagement measurements, over $60 \%$ of participants self-reported that they either strongly agreed or agreed with the item measured. Students particularly strongly agreed or agreed (78\%) that they checked their understanding of the industry-related concepts as they went along. Similarly, $75 \%$ of students either strongly agreed or agreed that, when preparing the Padlet, they tried to combine different pieces of information from the course material in new ways. It was clear that Padlet as a tool encouraged curiosity and provided the opportunity to present information in a new way providing an overall deeply cognitive learning experience.

Table 2. Cognitive engagement with the Padlet task $(n=320)$.

\begin{tabular}{|l|c|c|c|}
\hline \multicolumn{1}{|c|}{ Measurement Item } & $\begin{array}{c}\text { Strongly } \\
\text { agree/Agree }\end{array}$ & Neutral & $\begin{array}{c}\text { Disagree/Strongly } \\
\text { disagree }\end{array}$ \\
\hline $\begin{array}{l}\text { When approaching the Padlet task, I planned out } \\
\text { and organised my ideas based on how I wanted } \\
\text { my Padlet to look }\end{array}$ & $70 \%$ & $25 \%$ & $5 \%$ \\
\hline
\end{tabular}




\begin{tabular}{|l|c|c|c|}
\hline $\begin{array}{l}\text { When preparing my Padlet, I tried to combine } \\
\text { different pieces of information from the course } \\
\text { material in new ways }\end{array}$ & $75 \%$ & $20 \%$ & $5 \%$ \\
\hline $\begin{array}{l}\text { When preparing my Padlet, I tried to introduce } \\
\text { interesting new ideas of my own }\end{array}$ & $60 \%$ & $27 \%$ & $13 \%$ \\
\hline $\begin{array}{l}\text { When preparing my Padlet, if I did not understand } \\
\text { a concept I came across, I did some further } \\
\text { reading so I could understand it better }\end{array}$ & $68 \%$ & $18 \%$ & $14 \%$ \\
\hline $\begin{array}{l}\text { When preparing my Padlet, I checked my } \\
\text { understanding of the industry-related concepts as I } \\
\text { went along }\end{array}$ & $78 \%$ & $17 \%$ & $5 \%$ \\
\hline
\end{tabular}

\section{Discussion}

The overall aim of the case study was to find a way to encourage students to engage more deeply with a formative assessment. Given that previous cohorts had mentioned that they did not engage optimally with a written task, it was decided to design the task in a more engaging and creative way, and to introduce a technology to support creativity and flexibility, thus promoting greater student engagement in the task at hand. In the survey, $60 \%$ of students self-reported that they agreed or strongly agreed that they found the task cognitively engaging at a deep level across all measured items. Areas where cognitive engagement appeared to be particularly high were in checking understanding of specific concepts and in attempting to combine different pieces of information in new ways.

The evidence points towards the suitability of Padlet in supporting a learning design for cognitive engagement. It provided an engaging learning environment by allowing for higher levels of self-pacing, multi-modal representation, multiple points of access, collaborative discussion and reiterative learning. This success in facilitating cognitive engagement supports findings from the literature which suggest that learning technologies, when used effectively, can play a key role in stimulating curiosity and interest and in facilitating and sustaining engagement (Arnone et al., 2011). Given the students' active use of Padlet outside of timetabled hours, our case study also strengthens Fisher's (2017) view that Padlet is an easy-to-use technology and can be applied to engage students in a number of ways both inside and outside of the classroom. Furthermore, based on the cognitive engagement demonstrated, this case study offers a worthy approach to overall assessment for learning, not solely for formative purposes as demonstrated here. 


\section{Reflection and future practice}

What was presented here was an evidence-based scenario in which Padlet, an online elearning tool, could be used as an aid in a task designed to promote deep cognitive engagement amongst students. It was the experience of the module team that, given Padlet's ease of use, the task was seamless and easy to manage from an educator perspective. As such, this should encourage educators to seek ways to innovate in their teaching methods and to consider ways in which technologies can be employed pedagogically to promote learning and engagement.

The case also promotes exploring what other technologies could be used to support tasks designed to promote engagement or, alternatively, how the use of technologies might be used to support pedagogies of information representation and autonomous study, which, in themselves, serve as drivers of cognitive engagement (Smiley and Anderson, 2011). Padlet could also be used for other practices and to support other pedagogies. For instance, Padlet has been shown to improve the teacher-student relationship, increase motivation and self-esteem, and provide teachers with an alternative mode of communicating with students beyond the classroom (Rashid et al., 2019). Furthermore, regarding the recent shift to online teaching and a blended learning approach, Padlet lends itself well to this new climate, specifically given its potential for effective use in online, face-to-face, synchronous and asynchronous settings.

In addition, research has linked not only cognitive engagement to important educational outcomes such as student persistence in learning, satisfaction and academic achievement, but also behavioural and emotional engagement (Henrie et al., 2015). Thus, in future it would be useful to examine the use of digital technologies to support tasks to potentially promote all three types of student engagement. On reflection, the introduction of a student-friendly technology intervention is a worthy cause to facilitate engagement on the part of students given the already prevalent role of technology in the lives of students today. However, it is important to note that technology can be used superficially and in ways which are of no added value to students; thus, it is vital to ask the question of whether the incorporation of technology into instructional design is an enabler or a distraction. 
Reservations as to whether Padlet allows for the same level of analysis and synthesis associated with a written assessment were alleviated since students adequately demonstrated their ability to visually represent their chosen industry in a holistic way, indicating how both macro and microenvironment analyses of the industry impact the firm's position.

After the module, many students commented that they had enjoyed the Padlet task, and some had continued to use Padlet for other projects. It would be useful to evaluate the impact on the summative assessment and to examine whether a more cognitively engaging formative assessment leads to a higher success rate in the summative assessment. In summary, educators should feel free to explore ways in which digital technologies can be introduced to support learning design which facilitates engagement, motivation and participation, and above all achievement of learning outcomes.

\section{References}

Arnone, M.P., Small, R.V., Chauncey, S.A. and McKenna, H.P. (2011) 'Curiosity, interest and engagement in technology-pervasive learning environments: a new research agenda', Educational Technology Research and Development, 59(2), pp.181-198. Available at: https://doi.org/10.1007/s11423-011-9190-9 (Accessed 28 March 2021).

Blumenfeld, P., Kempler, T. and Krajcik, J. (2006) 'Motivation and cognitive engagement in learning environments', in Sawyer, K. (ed.) Cambridge handbook of the learning sciences. New York: Cambridge University Press, pp.475-488.

Bree, R.T. (2017) 'Incorporating augmented reality to enrich student learning'. Journal of Learning Development in Higher Education, 12, pp.1-12. Available at: https://doi.org/10.47408/jldhe.v0i12.400 (Accessed 28 March 2021). 
Corno, L. and Mandinach, E.B. (1983) 'The role of cognitive engagement in classroom learning and motivation', Educational psychologist, 18(2), pp.88-108. Available at: https://doi.org/10.1080/00461528309529266 (Accessed 28 March 2021).

Courville, K. (2011) 'Technology and its use in education: present roles and future prospects', Recovery School District Technology Summit, Baton Rouge, Louisiana 6-8 June. Available at: https://files.eric.ed.gov/fulltext/ED520220.pdf (Accessed 28 March 2021).

Dervan, P. (2014) 'Increasing in-class student engagement using Socrative (an online student response system)', All Ireland Journal of Higher Education, 6(3), pp.180193. Available at: https://ojs.aishe.org/index.php/aishe-j/article/view/180 (Accessed 28 March 2021).

DeWitt, D., and Koh, E. H. (2020) 'Promoting knowledge management processes through an interactive virtual wall in a postgraduate business finance course', Journal of Education for Business, 95(4), 255-262. Available at: https://doi.org/10.1080/08832323.2019.1635977 (Accessed 28 March 2021).

DeWitt, D., Alias, N. and Siraj, S. (2015) 'Collaborative learning: interactive debates using Padlet in a higher education institution', Journal of Educational Technology \& Society, 17(1), pp. 89-101. Available at: https://www.jstor.org/stable/jeductechsoci.17.1.89 (Accessed 28 March 2021).

Ellis, D. (2015) 'Using Padlet to increase student engagement in lectures', European Conference on eLearning. Hatfield, UK 29-30 October. Available at: https://core.ac.uk/download/pdf/228140577.pdf (Accessed 28 March 2021).

Fredricks, J. A., Blumenfeld, P. C. and Paris, A. H. (2004) 'School engagement: potential of the concept, state of the evidence', Review of educational research, 74(1), pp.59109. Available at: https://doi.org/10.3102\%2F00346543074001059 (Accessed 28 March 2021). 
Fisher, C. D. (2017) 'Padlet: an online tool for learner engagement and collaboration', Academy of Management Learning and Education, 16(1), pp.163-165. Available at: https://doi.org/10.5465/amle.2017.0055 (Accessed 28 March 2021).

Greene, B.A. (2015) 'Measuring cognitive engagement with self-report scales: reflections from over 20 years of research', Educational Psychologist, 50(1), pp.14-30. Available at: https://doi.org/10.1080/00461520.2014.989230 (Accessed 28 March 2021).

Greene, B. A. and Miller, R. B. (1996) 'Influences on achievement: goals, perceived ability, and cognitive engagement', Contemporary Educational Psychology, 21(2), pp.181192. Available at: https://doi.org/10.1006/ceps.1996.0015 (Accessed 28 March 2021).

Gurung, B. and Rutledge, D. (2014) 'Digital learners and the overlapping of their personal and educational digital engagement', Computers \& Education, 77, pp.91-100. Available at: https://doi.org/10.1016/j.compedu.2014.04.012 (Accessed 28 March 2021).

Henrie, C.R., Halverson, L.R. and Graham, C.R. (2015) 'Measuring student engagement in technology-mediated learning: a review', Computers \& Education, 90, pp.36-53. Available at: https://doi.org/10.1016//.compedu.2015.09.005 (Accessed 28 March 2021).

Hockings, C. (2010) Inclusive learning and teaching in higher education: a synthesis of research. Available at: https://www.advance-he.ac.uk/knowledge-hub/inclusivelearning-and-teaching-higher-education-synthesis-research (Accessed 28 March 2021).

Kuh, G.D. and Hu, S. (2001) 'The relationships between computer and information technology use, selected learning and personal development outcomes, and other college experiences', Journal of College Student Development, 42(3), pp.217-232. 
Available at: https://psycnet.apa.org/record/2001-06432-003 (Accessed 28 March 2021).

Laird, T.F.N. and Kuh, G.D. (2005) 'Student experiences with information technology and their relationship to other aspects of student engagement', Research in Higher education, 46(2), pp.211-233. Available at: https://doi.org/10.1007/s11162-0041600-y (Accessed 28 March 2021).

Light, G., Calkins, S. and Cox, R. (2009) Learning and teaching in higher education: the reflective professional. London: Sage Publications Ltd.

Mo, S. (2011) 'Evidence on instructional technology and student engagement in an auditing course', Academy of Educational Leadership Journal, 15(4), pp.149-158. Available at: https://www.abacademies.org/articles/aeljvol15no42011.pdf (Accessed 28 March 2021).

Park, S.W. (2013) 'The potential of Web 2.0 tools to promote reading engagement in a general education course'. TechTrends, 57(2), pp.46-53. Available at: https://link.springer.com/content/pdf/10.1007/s11528-013-0645-1.pdf (Accessed 28 March 2021).

Rashid, A.A., Yunus, M.M. and Wahi, W. (2019) 'Using Padlet for collaborative writing among ESL learners', Creative Education, 10(3), pp.610-620. Available at: https://doi.org/10.4236/ce.2019.103044 (Accessed 28 March 2021).

Richardson, J.C. and Newby, T. (2006) 'The role of students' cognitive engagement in online learning', American Journal of Distance Education, 20(1), pp.23-37. Available at: https://doi.org/10.1207/s15389286ajde2001 3 (Accessed 28 March 2021).

Schindler, L.A., Burkholder, G.J., Morad, O.A. and Marsh, C. (2017) 'Computer-based technology and student engagement: a critical review of the literature', International Journal of Educational Technology in Higher Education, 14(1), pp.1-28. Available at: https://doi.org/10.1186/s41239-017-0063-0 (Accessed 28 March 2021) 
Scott, J.E. and Walczak, S. (2009) 'Cognitive engagement with a multimedia ERP training tool: assessing computer self-efficacy and technology acceptance, Information \& Management, 46(4), pp.221-232. Available at: https://doi.org/10.1016/i.im.2008.10.003 (Accessed 28 March 2021).

Shinde, J. (2020) 'Faculty experiences of delivering blended learning courses', in Mishra, S. and Panda, S. (eds.) Technology enabled learning: policy, pedagogy and practice. Burnaby: The Commonwealth of Learning, pp.71-84.

Smiley, W. and Anderson, R. (2011) 'Measuring students' cognitive engagement on assessment tests: a confirmatory factor analysis of the short form of the cognitive engagement scale', Research \& Practice in Assessment, 6, pp. 17-28. Available at: https://www.rpajournal.com/measuring-students-cognitive-engagement-onassessment-tests-a-confirmatory-factor-analysis-of-the-short-form-of-the-cognitiveengagement-scale/ (Accessed 28 March 2021).

\section{Author details}

Lucy Gill-Simmen is a Senior Lecturer in Marketing. She is a Senior Fellow of the Higher Education Academy and is the Program Director for Royal Holloway, University of London, Kaplan, Singapore. 